\title{
Recent advances in understanding and managing rosacea
}

\section{[version 1; peer review: 3 approved]}

\author{
Joerg Buddenkotte (iD) 1,2, Martin Steinhoff1-5 \\ ${ }^{1}$ Department of Dermatology and Venereology, Hamad Medical Corporation, Doha, Qatar \\ ${ }^{2}$ Translational Research Institute, Hamad Medical Corporation, Doha, Qatar \\ ${ }^{3}$ Weill Cornell Medicine-Qatar, Doha, Qatar \\ ${ }^{4}$ Medical School, Qatar University, Doha, Qatar \\ ${ }^{5}$ Weill Cornell Medicine, New York, NY, USA
}

V1 First published: 03 Dec 2018, 7(F1000 Faculty Rev):1885
https://doi.org/10.12688/f1000research.16537.1

Latest published: 03 Dec 2018, 7(F1000 Faculty Rev):1885

https://doi.org/10.12688/f1000research.16537.1

\section{Abstract}

Rosacea is a common chronic inflammatory skin disease of the central facial skin and is of unknown origin. Currently, two classifications of rosacea exist that are based on either "preformed" clinical subtypes (erythematotelangiectatic, papulopustular, phymatous, and ocular) or patient-tailored analysis of the presented rosacea phenotype. Rosacea etiology and pathophysiology are poorly understood. However, recent findings indicate that genetic and environmental components can trigger rosacea initiation and aggravation by dysregulation of the innate and adaptive immune system. Trigger factors also lead to the release of various mediators such as keratinocytes (for example, cathelicidin, vascular endothelial growth factor, and endothelin-1), endothelial cells (nitric oxide), mast cells (cathelicidin and matrix metalloproteinases), macrophages (interferon-gamma, tumor necrosis factor, matrix metalloproteinases, and interleukin-26), and $T$ helper type $1\left(T_{H} 1\right)$ and $T_{H} 17$ cells. Additionally, trigger factors can directly communicate to the cutaneous nervous system and, by neurovascular and neuro-immune active neuropeptides, lead to the manifestation of rosacea lesions. Here, we aim to summarize the recent advances that preceded the new rosacea classification and address a symptom-based approach in the management of patients with rosacea.

\section{Keywords}

Rosacea, Classification, Pathophysiology, Inflammation, Cathelicidin, Immunity, Therapy

\section{Open Peer Review}

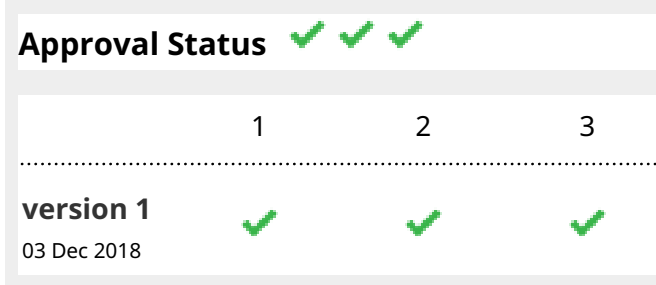

Faculty Reviews are review articles written by the prestigious Members of Faculty Opinions. The articles are commissioned and peer reviewed before publication to ensure that the final, published version is comprehensive and accessible. The reviewers who approved the final version are listed with their names and affiliations.

1. Steven R Feldman, Wake Forest School of Medicine, Winston-Salem, USA

2. Adam Reich (ID), University of Rzeszów, Rzeszów, Poland

\section{Jacob Pontoppidan Thyssen, Herlev and}

Gentofte Hospital, University of Copenhagen, Hellerup, Denmark

Any comments on the article can be found at the end of the article. 
Corresponding author: Martin Steinhoff (MSteinhoff@hamad.qa)

Author roles: Buddenkotte J: Conceptualization, Writing - Original Draft Preparation, Writing - Review \& Editing; Steinhoff M: Conceptualization, Writing - Original Draft Preparation, Writing - Review \& Editing

Competing interests: No competing interests were disclosed.

Grant information: The author(s) declared that no grants were involved in supporting this work.

Copyright: ( $) 2018$ Buddenkotte J and Steinhoff M. This is an open access article distributed under the terms of the Creative Commons Attribution License, which permits unrestricted use, distribution, and reproduction in any medium, provided the original work is properly cited.

How to cite this article: Buddenkotte $J$ and Steinhoff $M$. Recent advances in understanding and managing rosacea [version 1; peer review: 3 approved] F1000Research 2018, 7(F1000 Faculty Rev):1885 https://doi.org/10.12688/f1000research.16537.1

First published: 03 Dec 2018, 7(F1000 Faculty Rev):1885 https://doi.org/10.12688/f1000research.16537.1 


\section{From old to new rosacea classification}

The first classification of rosacea was published in 2002, recognizing rosacea as a syndrome that is comprehensively depicted by four distinct clinical subtypes defined as erythematotelangiectatic, papulopustular, phymatous, and ocular rosacea ${ }^{1}$. The classification was the first to systemize rosacea diagnosis in the daily medical routine and gave resilient criteria at hand to efficiently evaluate therapeutic success in each subtype. The implementation of this new tool in the medical daily routine prompted a marked improvement in the medical care of rosacea patients worldwide. In general, the classification suggests a progression from one subtype to another over time and thereby supports a tendency to disregard deviating rosacea manifestations and overlaps between the subtypes. The progress in scientific insight that was accumulated since the introduction of the original rosacea classification in combination with our detailed clinical experience favored a modernized view of rosacea's pathophysiology as a product of multivariate disease processes that underlie the patient-specific clinical rosacea presentations ${ }^{2,3}$. An updated rosacea classification was published in 2016, emphasizing a more patient-centric phenotype approach ${ }^{4,5}$. This review aims to summarize the recent developments in our understanding of rosacea's pathophysiology that preceded the release of the modified rosacea classification and to illustrate the therapeutic management of individual rosacea patients on the basis of their symptoms.

\section{Epidemiology and diagnosis of rosacea}

In the US alone, more than 16 million patients are affected by rosacea, and worldwide incidences peak as high as $18 \%$, particularly in populations with a predominant "Celtic" heritage, such as is observed in Ireland ${ }^{6}$. Worldwide, the prevalence is estimated to reach over 5\%. Females and males are affected equally ${ }^{7}$. However, the prevalence of rosacea in many countries, including large countries like China and Australia, is still poorly explored, and the prevalence, especially of erythematous rosacea, demands careful differentiation from that of other erythematous diseases and origins of flushing, such as neuroendocrine tumors.

Rosacea typically arises symmetrically in the central face with gender- and age-specific preferences with regard to lesion qualities. For instance, rhinophyma nearly exclusively presents in the male gender, flushing and erythema often are the first disease signs in younger ages, and telangiectasias make up first rosacea lesions in older ages. The overall rosacea manifestations are flushing, transient or persistent erythema, telangiectasia, papules, pustules, phymata, and (micro)edema (Table 1) ) $^{1,8}$. Additionally, patients often report stinging or burning pain and very rarely pruritic sensations. Despite the typical centro-facial localization of rosacea, a causative association with the unique centro-facial skin composition that is characterized by a dense presence of sebaceous glands, dense nerval and vascular networks, and Demodex mites cannot be drawn conclusively as of yet. However, Demodex infestation is increased in some patients with rosacea, and eradication seems to alleviate rosacea symptoms probably by preventing the formation of pro-inflammatory cytokines ${ }^{9,10}$.

The patient's awareness about rosacea's centro-facial localization often promotes severe psychosocial symptoms, including impaired self-esteem, problems in socializing, and changes in the way the patient thinks, feels, or copes. Recent epidemiological studies confirm these clinical observations and report significant psychological disease burden and decreased quality of life in patients with rosacea ${ }^{11-16}$.

Rosacea can be initiated or aggravated by a variety of endogenous and exogenous trigger factors, including heat, noxious cold, ultraviolet (UV) irradiation, and food and beverages. Activation pathways to some of the rosacea triggers have been delineated recently (Table 2) and might point to future therapeutic targets. The identification of patient-specific trigger factors represents the main and fundamental pillar of rosacea therapy and enables selective and therapeutic trigger avoidance. This strategy in particular is helpful to prevent or alleviate rosacea manifestations that respond dynamically to a trigger such as flushing and transient erythema. In general, the individual clinical manifestation of rosacea appears to be influenced by the special trigger constellation and susceptibilities of a patient. For instance, a bald patient with an enhanced susceptibility toward UV irradiation is imperiled to develop frontoparietal papulopustular lesions, whereas a patient devoid of UV susceptibility is less likely to develop similar rosacea lesions.

The newly introduced classification of rosacea emphasizes the importance of each rosacea manifestation and distinguishes diagnostic features (signs) from major and secondary features (symptoms) (Table 1) ${ }^{17}$. Briefly, phymatous changes and persistent centro-facial erythema are considered the only diagnostic features (signs) of rosacea, whereas flushing, telangiectasia, and

Table 1. Novel classification of rosacea on the basis of diagnostic, major, and secondary features of rosacea.

\begin{tabular}{|l|l|l|}
\hline Diagnostic features & Major features & Secondary features \\
\hline $\begin{array}{l}\text { Persistent centro-facial erythema associated } \\
\text { with aggravation by trigger factors }\end{array}$ & Flushing/transient erythema & Burning sensation \\
\hline Phymatous changes & Inflammatory papules and pustules & Stinging sensation \\
\hline & Telangiectasia & Edema \\
\hline & $\begin{array}{l}\text { Ocular manifestations } \\
\text { Lid margin telangiectasia } \\
\text { Blepharitis, keratitis, conjunctivitis, and sclerokeratitis }\end{array}$ & $\begin{array}{l}\text { Dry sensation of the } \\
\text { skin }\end{array}$ \\
\hline
\end{tabular}

Adapted from Gallo et al. ${ }^{2}$ and Tan et al. ${ }^{17}$ 
Table 2. Common rosacea triggers and their activation pathways and current therapy regimen.

\begin{tabular}{|c|c|c|}
\hline $\begin{array}{l}\text { Pathway of } \\
\text { activation }\end{array}$ & Trigger & Therapeutic regimen \\
\hline $\begin{array}{l}\text { Inflammasome } \\
\text { (NALP3) }\end{array}$ & $\begin{array}{l}\text { Sun exposure, wind, heavy exercise, alcohol consumption, emotional stress, skin } \\
\text { care products and cosmetics (formaldehyde), medication, and microorganisms }\end{array}$ & $\begin{array}{l}\text { Avoidance, anti-inflammatory therapy, } \\
\text { and antibiotics }\end{array}$ \\
\hline TLR-2 & $\begin{array}{l}\text { Sun exposure, emotional stress, alcohol, exercise, microorganisms/gut } \\
\text { microbiome, topicals, and medication }\end{array}$ & $\begin{array}{l}\text { Avoidance, } 30+\text { SPF sunscreen, and } \\
\text { brimonidine }\end{array}$ \\
\hline TRPV1 & $\begin{array}{l}\text { Emotional stress, heat/hot weather/hot steam, exercise, alcohol, and spicy food } \\
\text { (capsaicin) }\end{array}$ & Avoidance and brimonidine \\
\hline TRPV2 & Heat & Avoidance \\
\hline TRPV4 & Sun exposure/ultraviolet irradiation, humidity, and osmotic changes & Avoidance and 30+ SPF sunscreen \\
\hline TRPA1 & $\begin{array}{l}\text { Cold weather, garlic/mustard oil (pungency), and skin care products and } \\
\text { cosmetics (formaldehyde) }\end{array}$ & Avoidance and brimonidine \\
\hline $\mathrm{PAR}_{2}$ & Proteinases and microorganisms & $\begin{array}{l}\text { Anti-inflammatory therapy and } \\
\text { antibiotics }\end{array}$ \\
\hline
\end{tabular}

NALP3, NACHT, LRR, and PYD domain-containing protein 3; PAR, proteinase-activated receptor 2; SPF, sun protection factor; TLR-2, Toll-like receptor 2; TRPA1, transient receptor potential ankyrin 1; TRPV, transient receptor potential vanilloid.

inflammatory papules/pustules are considered major symptoms and only in combination can suggest the diagnosis of rosacea. Stinging or burning pain, edema, and dry sensation are defined as secondary features of rosacea (Table 1).

\section{Novelties in the pathophysiology of rosacea}

Rosacea skin is characterized by dysregulated inflammatory (perivascular or pilosebaceous infiltrate), vascular (dilation), lymphatic (dilation), glandular (hyperplasia), and fibrotic processes, a composition that reflects the multivariate process of the skin disease. Simultaneously, this heterogeneous histological picture hints at rosacea's unclear pathophysiologic event of onset. Does rosacea originate from an initial dysregulation in inflammatory processes? Is rosacea a disease of the vasculature or rather of the lymphatic system? Does it result from glandular tissue? Or does rosacea represent a skin disease that ultimately arises from combined dysfunctional systems that could involve the gut?

\section{Immunity}

The adaptive immune system along with the innate immune system might take a central part in rosacea's pathophysiology. Both the early stage perivascular and later-stage pilosebaceous infiltrates are strongly composed of $\mathrm{T}$ helper type $1\left(\mathrm{~T}_{\mathrm{H}} 1\right)$ and $\mathrm{T}_{\mathrm{H}} 17$ cells and show marked expression of innate immune cells such as additional macrophages and mast cells in papules and erythema and additional neutrophils in pustules and plasma cells in phymata ${ }^{18,19}$. CD4 ${ }^{+} \mathrm{T}_{\mathrm{H}}$ cells dominate the immune cell infiltrate, but overall rosacea, like its differential diagnosis acne vulgaris, displays a $T_{H} 1 / T_{H} 17$ polarization pattern ${ }^{20}$. These immuno-histochemical findings have been confirmed by transcriptome analysis, where markedly elevated expressions of $T_{H} 1$ signature genes-interferon-gamma and tumor necrosis factoralpha (TNF- $\alpha$ ) - and upregulated expression of $\mathrm{T}_{\mathrm{H}} 17$-associated genes coding for IL17A, IL22, IL6, IL20, and CCL20 were found. Neither $\mathrm{T}_{\mathrm{H}} 2$-associated genes nor signature markers for regulatory T cells (FOXP3, IL10, CCR4, and CCR8) were found to be altered in the expression in rosacea when compared with healthy $\operatorname{skin}^{19}$. In acne vulgaris, Propionibacterium acnes capably drives the polarization of the immune cell infiltrate to a $T_{H} 1 /$ $\mathrm{T}_{\mathrm{H}} 17$ type $^{21,22}$. This mechanism too could be of importance in rosacea, since some studies could associate patient colonization with Demodex spp., Bacillus oleronius, Staphylococcus epidermidis, Helicobacter pylori, and Bartonella quintana with the development of rosacea ${ }^{19,23-25}$. Rosacea's association with facial Demodex spp. colonization was described quite some time ago, but its consequence for rosacea pathophysiology is still not understood and is even disputed by some. These concerns were substantiated by multiple clinical trials that achieved a reduction or eradication of Demodex colonization but often did not observe a marked amelioration of the clinical presentation in patients ${ }^{26}$. However, in case microbes initiate the shift of the infiltrate observed in rosacea toward a stable $T_{H} 1 / T_{H} 17$ polarization, eradication of an "early" rosacea signal might have a smaller therapeutic effect than anticipated in later disease stages. The causative role of especially Demodex spp. and Demodex-dependent and -independent microbes for the $T_{H} 1 / T_{H} 17$ polarization observed in rosacea will need to be investigated, and the importance of the T-cell pattern for the initiation and perpetuation of rosacea is in need of detailed clarification.

Another pathogen that has been suggested to be involved in the pathophysiology of rosacea is $H$. pylori ${ }^{27,28}$. However, a recent meta-analysis found only a weak association between $H$. pylori infection and rosacea and between successful eradication of $H$. pylori and improvement of rosacea manifestations ${ }^{29}$.

\section{Microbes and the cathelicidin axis in rosacea}

Products of microbes can be recognized by cells of the innate immune system and activate, for example, Toll-like receptors (TLRs) and the G-protein-coupled receptor proteinase-activated receptor $2\left(\mathrm{PAR}_{2}\right)$ that are expressed by keratinocytes and can nurture inflammatory processes ${ }^{30}$. Notably, TLR-2 and probably $\mathrm{PAR}_{2}$ are upregulated in patients with rosacea, and in vitro 
activation of both receptors promotes the activation of cathelicidin, an anti-microbial peptide that is also overexpressed in patients with rosacea (Figure 1) ${ }^{30,31}$. TLR-2 signaling can further activate the NLRP3 inflammasome with subsequent IL-1 $\beta$ - and TNF-mediated inflammation amplification and prostaglandin $\mathrm{E}_{2}$ synthesis, which support pustule formation, pain sensation, and vascular responses ${ }^{32}$. TLR-2 activation additionally promotes the release of pro-inflammatory cytokines, chemokines, proteases, and pro-angiogenic factors, which are mediators associated with rosacea symptoms such as erythema, telangiectasia, or inflammation or a combination of these $\mathrm{e}^{10,33-35}$. A direct link among Demodex mites, microbes, and PAR 2 or TLR-2 has not yet been demonstrated in rosacea. Also, functional in vivo data for cathelicidin in humans are still lacking. In mice, TLR-2-induced cathelicidin activation needs functional kallikrein-5 (KLK-5) protease activity for the formation of rosacea-like erythema and angiogenesis ${ }^{36}$. However, KLK-5 is increased in patients with rosacea and $\mathrm{KLK}(\mathrm{s})-5$ can activate $\mathrm{PAR}_{2}{ }^{37}$. $\mathrm{PAR}_{2}$ is a known mediator of (neuro)inflammation, pruritus and pain sensation, T-cell and neutrophil recruitment to sites of inflammation, mast cell degranulation and vasodilation, and promotion of release of inflammatory mediators such as IL-1, IL-6, IL-8, TNF, chemokines, matrix metalloproteinases, and prostaglandins ${ }^{38}$. $\mathrm{PAR}_{2}$ is expressed by various skin cell types, including keratinocytes, endothelial cells, and innate and adaptive immune cells, activated by microbe-derived proteases, and interacts with TLRs ${ }^{39-43}$. The upstream signal or signals of enhanced PAR 2 , TLR-2, and KLK-5 proteins in rosacea have not been identified yet. However, vitamin D can increase TLR-2 and KLK-5 expression in keratinocytes and is found in excess in some patients with rosacea and might be a candidate (Figure 1$)^{44}$. Further activation of proinflammatory receptors (for example, PAR $_{2}$ ) can lead to a secondary skin barrier deficit which may lead to more inflammation ${ }^{45,46}$.

The importance of microbes and microbe-associated products and their respective target receptor(s) for rosacea pathophysiology is further supported by the recent observation that rosacea patients with SIBO (small intestinal bacterial overgrowth)

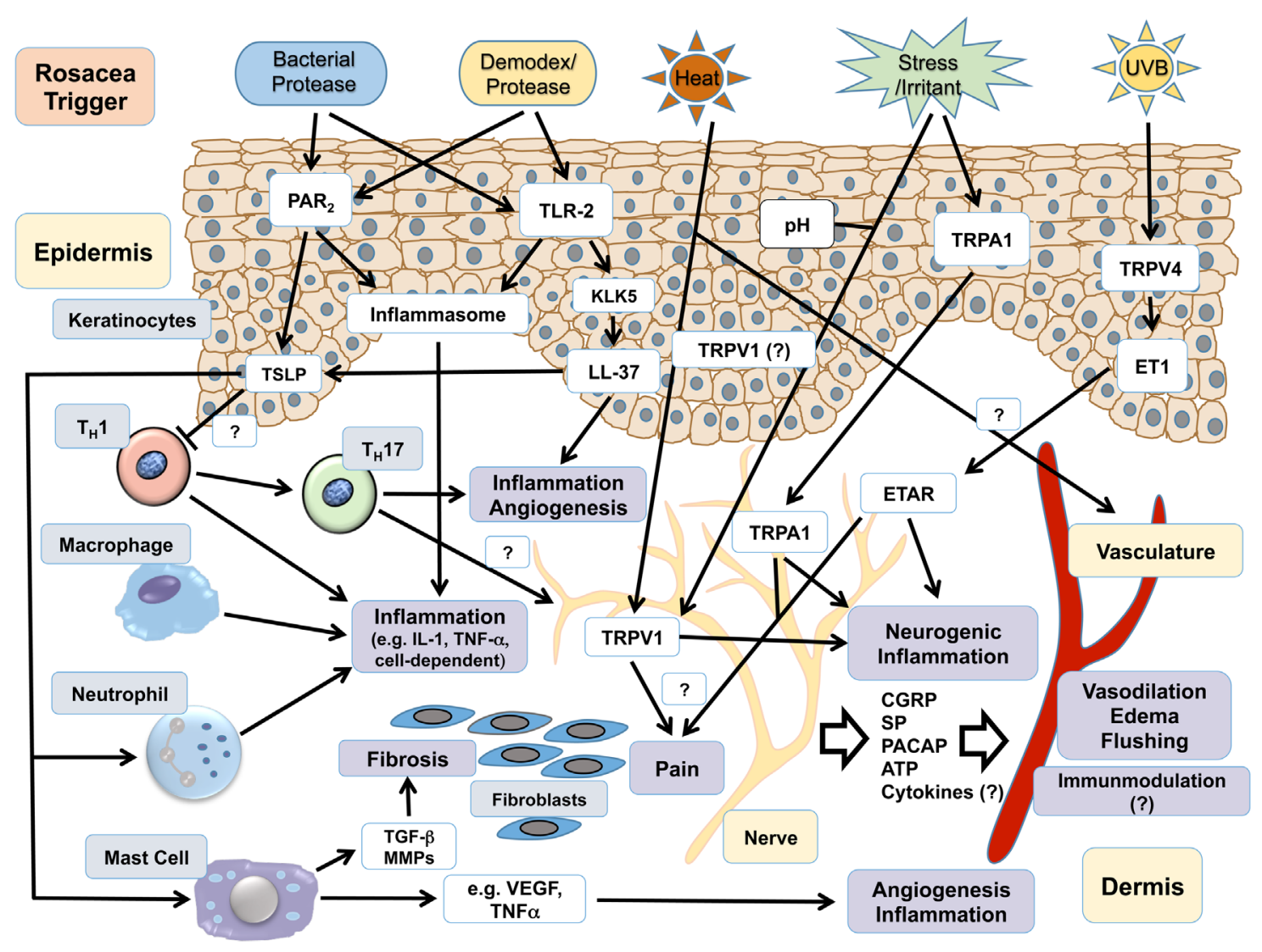

Figure 1. Current understanding of the pathomechanisms in rosacea. Rosacea triggers lead to the activation of downstream effectors (white boxes) in various cell types (gray boxes) probably by the activation of a few specific receptors and channels (white boxes), which in cooperation nurture processes of (neurogenic) inflammation, including edema and vasodilation, fibrosis, pain, and angiogenesis (lilac boxes). For instance, epidermal and probably immune cell-expressed proteinase-activated receptor-2 (PAR ${ }_{2}$ ) and Toll-like receptor-2 (TLR-2) are activated by rosacea-associated bacterial and Demodex-derived proteases, leading to the induction of the inflammasome and subsequent release of pro-inflammatory agents such as tumor necrosis factor-alpha (TNF- $\alpha$ ) and interleukin-1 (IL-1) as well as enhanced expression of the innate immune peptide LL-37. ATP, adenosine triphosphate; CGRP, calcitonin gene-related peptide; ET1, endothelin-1; ETAR, endothelin A receptor; KLK-5, kallikrein-5; LL-37, cathelicidin; MMP, matrix metalloproteinase; NALP3, NACHT, LRR, and PYD domain-containing protein 3; PACAP, pituitary adenylate cyclase-activating peptide; SP, substance P; TGF- $\beta$, transforming growth factor-beta; TRP, transient receptor potential; TSLP, thymic stromal lymphopoietin; VEGF, vascular endothelial growth factor. 
benefit from treatment with the T-cell modulator rifaximin and present with improved rosacea symptoms ${ }^{47-50}$.

\section{Neurovascular processes and neurogenic inflammation in rosacea}

Patients with rosacea react to a vast panel of trigger factors such as temperature changes, heat, cold, exercise, UV radiation, and spicy food and alcoholic beverages with deterioration of rosacea lesions ${ }^{51}$. The precise mediating receptors and messengers for each trigger factor are in most cases not identified, but recent transcriptomic analysis and immunohistochemical findings indicate that the transient receptor potential family-in particular, members of the ankyrin subfamily (TRPA1) and the vanilloid subfamily (TRPV1 and TRPV4) - might convey cellular responses to several of the rosacea-specific trigger factors ${ }^{52,53}$. TRPV1 and TRPA1 are well-described targets for various pungent compounds such as capsaicin (TRPV1) and mustard oil (TRPA1 and TRPV 1$)^{54}$ and could render rosacea stimuli such as heat $(\text { TRPV } 1)^{55}$, possibly cold temperatures (TRPA 1$)^{56}$, UVB irradiation (TRPV4) ${ }^{57}$, and toxins and cosmetics ingredients (for example, TRPA 1$)^{58}$ into clinical rosacea manifestations. In particular, neuronally expressed TRP channels could be responsible for the activation of the cutaneous vasculature leading to flushing, one hallmark feature of rosacea, and erythema by a neurovascular mechanism involving neurogenic inflammation

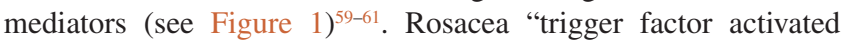
TRP channels" in fact lead to the release of vasoactive neuropeptides such as substance $\mathrm{P}$ (SP), pituitary adenylate cyclaseactivating peptide (PACAP), and the migraine-associated calcitonin gene-related peptide (CGRP) ${ }^{61-63}$. Sensory nerves also express the neuro-inflammatory TLR-2 and PAR, which might perpetuate the neurovascular dysregulation observed in rosacea. Because TRP channels (particularly TRPA1 and TRPV1) and $\mathrm{PAR}_{2}$ can crosstalk with neuropeptide receptors or at least trigger neuropeptide release, these interactions could help to sustain the neurovascular loop and neurogenic inflammation in rosacea ${ }^{52,53,64}$.

Along sensory nerves, dysregulation of the autonomic nervous system (ANS) can produce facial flushing. However, a distinct role for this mechanism in rosacea-typical flushing is not confirmed at this stage but could be promoted by ANS-expressed PACAP or stress-induced increase of skin sympathetic nerve activity ${ }^{65-67}$. In summary, the neurovascular circuits that appear to be involved in rosacea's pathophysiology might explain the patient-specific trigger profiles and differences in the clinical presentation of rosacea. Altered downstream signaling and target structures might account for the phenotypic variability observed in rosacea.

\section{Genetics of rosacea}

The existence of genetic traits that underlie rosacea is expressed by a positive family history for rosacea. Only recently, a handful of genome-wide association studies have been conducted that propose genetic risk loci for rosacea. An American study included individuals of European descent (all customers of the genetic company 23andme, Mountain View, CA, USA) identified singlenucleotide polymorphisms in the butyrophilin-like 2 (BTNL2) and the human leukocyte antigen-DRA genes. Both genes are associated with the major histocompatibility complex of the acquired immune system, indicating a central role for dysregulations of the immune system in rosacea's pathogenesis. Another study found a null mutation polymorphism in the glutathione S-transferase (GST) gene that encodes for an enzyme involved in cellular oxidative stress ${ }^{68,69}$. In a case study of a patient with granulomatous rosacea, a polymorphism in the NOD2/CARD15 gene was observed ${ }^{70}$. NOD2/CARD15 protein functions as a caspase recruitment protein and is associated with the function of innate immune system receptors such as TLR-2 and subsequent inflammatory processes. Interestingly, a recent populationbased case control study revealed that rosacea shares genetic risk loci with various autoimmune diseases such as multiple sclerosis, type 1 diabetes mellitus, celiac disease, and rheumatoid arthritis. This observation underlines the importance of a thorough risk assessment for the individual patient with rosacea at risk of developing an autoimmune disorder so that multidisciplinary medical care can be organized for affected patients ${ }^{71}$.

\section{Therapeutic management of rosacea}

\section{General skin care}

Consequent adherence to skin care advice and consequent application of adequate non-irritating skin care can significantly prevent events of rosacea aggravation and improve the patient's quality of life. Skin care advice consists primarily of avoidance of trigger factors (including stress management), usage of sunscreen with $30+$ sun protection factor, application of moisturizers for dry skin and drying applications for oily skin, and gentle cleansing of the whole face ${ }^{72}$.

\section{Symptom-based treatment}

Because rosacea symptoms derive from distinct pathophysiologies, the therapeutic regimen will in most cases consist of combinations of topicals with systemics or physical therapy or both ${ }^{73,74}$.

\section{Flushing and erythema}

According to recent guidelines, two approved topicals can be used to treat persistent erythema in adults with rosacea: brimonidine ${ }^{75-77}$ (a beta2-adrenergic agonist) and oxymetazoline hydrochloride 1\% cream $^{78}$ (an alpha1A-adrenoreceptor agonist that also activates alpha2-receptors at higher concentrations) $)^{4,17,72,73}$.

Certain laser therapies can be used, but they should be avoided in pain-sensitized patients ${ }^{79-81}$. Off-label usage of beta-blockers such as carvedilol or adrenergic receptor modulators (for example, brimonidine) may alleviate these symptoms ${ }^{80}$. In case of pain association, an analgesic therapy with, for instance, lidocaine gel $(4 \%)$ or polidocanol cream in mild cases and antiphlogistics (for example, ibuprofen), anti-depressants (for example, amitriptyline), or anticonvulsants (for example, gabapentin and pregabalin) in more severe cases may be helpful ${ }^{82}$.

\section{Telangiectasia}

Only a few options exist for the treatment of telangiectasia, among which physical laser therapy and intravascular aethoxysklerol $(0.5 \%-1 \%)$ injections are most commonly used. 


\section{Papules and pustules}

Patients with mild to moderate papules and pustules benefit from topical treatment with ivermectin $(1 \%)^{83}$, metronidazole $(1 \%)^{84-86}$, azelaic acid $(15 \%)^{87}$, or sodium sulfacetamide sulfur ${ }^{88}$. Off-label therapy with topical erythromycin (2\%), isotretinoin, clindamycin, permethrin, doxycycline, minocycline, and oral erythromycin has been reported with good results. Combination therapy often helps to prolong symptom-free periods. In severe or therapy-refractory cases, systemic treatment with metronidazole, clarithromycin, and azithromycin can be conducted. In cases of Demodex infestation, permethrin (off-label) or ivermectin cream and oral ivermectin can improve the therapeutic result $^{72,89}$.

\section{Phymata}

Patients affected by mild phymata benefit from tetracycline therapy. Standard therapies for progressed phymata are ablative (destructive) laser and dermato-surgery. Low-dose isotretinoin appears to reduce phymata by its anti-inflammatory capacity and by lessening the number of sebaceous glands and inhibiting their proliferation $^{90-92}$. Systemic immunomodulatory therapy such as dapsone was used in some cases with mixed results.

\section{Facial (lymph)edema}

No US Food and Drug Administration-approved therapy exists. Immunomodulators such as isotretinoin and dapsone or combination therapies with doxycycline/prednisolone have been tried, but the therapeutic value is unclear ${ }^{93}$.

\section{Ocular rosacea}

The appropriate treatment of ocular rosacea requires a multidisciplinary effort from ophthalmologists and dermatologists.
Basic lid hygiene routines such as warm compresses and lubricating drops can be conducted by the patient. Artificial tear substitutes help ocular dryness and accompanying burning and stinging. Successful therapy with topical ivermectin was recently reported ${ }^{94}$. In more severe cases, cyclosporine eye drops and systemic tetracycline can be prescribed ${ }^{73}$.

\section{Summary and future directions}

Basic, translational, and clinical research has significantly increased our understanding of a common skin disease, rosacea, leading to novel anti-inflammatory and anti-erythematous treatments. Combination therapies, similar to those for acne and atopic dermatitis, are a key for the successful therapy of this poly-symptomatic disease ${ }^{95}$.

Several questions remain to be answered: which genes are involved in rosacea? What is the prevalence of rosacea globally? Which are the key mediators and receptors of rosacea in the various clinical symptoms and signs? Which comorbidities are associated with rosacea? How can we optimize the diagnosis and treatment of rosacea? Translational research is demanded to better understand and treat this commonly neglected skin disease.

\section{Grant information}

The author(s) declared that no grants were involved in supporting this work.

\section{Acknowledgments}

We thank Hasna Amal Boumenar for proofreading the manuscript and assisting in the preparation of Figure 1.
1. Wilkin J, Dahl M, Detmar M, et al.: Standard classification of rosacea: Report of the National Rosacea Society Expert Committee on the Classification and Staging of Rosacea. J Am Acad Dermatol. 2002; 46(4): 584-7. PubMed Abstract | Publisher Full Text

2. Gallo RL, Granstein RD, Kang S, et al:: Standard classification and pathophysiology of rosacea: The 2017 update by the National Rosacea Society Expert Committee. J Am Acad Dermatol. 2018; 78(1): 148-55. PubMed Abstract | Publisher Full Text

3. Tan J, Steinhoff M, Berg M, et al:: Shortcomings in rosacea diagnosis and classification. Br J Dermatol. 2017; 176(1): 197-9. PubMed Abstract | Publisher Full Text

4. Gallo RL, Granstein RD, Kang S, et al.: Rosacea comorbidities and future research: The 2017 update by the National Rosacea Society Expert Committee. J Am Acad Dermatol. 2018; 78(1): 167-70. PubMed Abstract | Publisher Full Text

5. $\quad F$ Tan J, Berg M, Gallo RL, et al:: Applying the phenotype approach for rosacea to practice and research. Br J Dermatol. 2018; 179(3): 741-6. PubMed Abstract | Publisher Full Text | F1000 Recommendation

6. Tan J, Berg M: Rosacea: current state of epidemiology. J Am Acad Dermatol. 2013; 69(6 Suppl 1): S27-35. PubMed Abstract | Publisher Full Text

7. $\mathrm{F}$ Gether L, Overgaard LK, Egeberg A, et al.: Incidence and prevalence of rosacea: a systematic review and meta-analysis. Br J Dermatol. 2018; 179(2): 282-9.

PubMed Abstract | Publisher Full Text | F1000 Recommendation

8. Powell FC: Clinical practice. Rosacea. N Engl J Med. 2005; 352(8): 793-803. PubMed Abstract | Publisher Full Text
9. Sattler EC, Hoffmann VS, Ruzicka T, et al.: Reflectance confocal microscopy for monitoring the density of Demodex mites in patients with rosacea before and after treatment. Br J Dermatol. 2015; 173(1): 69-75. PubMed Abstract | Publisher Full Text

10. Casas C, Paul C, Lahfa M, et al:: Quantification of Demodex folliculorum by PCR in rosacea and its relationship to skin innate immune activation. Exp Dermatol. 2012; 21(12): 906-10.

PubMed Abstract | Publisher Full Text

11. F Egeberg A, Hansen PR, Gislason GH, et al:: Patients with Rosacea Have Increased Risk of Depression and Anxiety Disorders: A Danish Nationwide Cohort Study. Dermatology. 2016; 232(2): 208-13.

PubMed Abstract | Publisher Full Text | F1000 Recommendation

12. F Bewley A, Fowler J, Schöfer H, et al.: Erythema of Rosacea Impairs HealthRelated Quality of Life: Results of a Meta-analysis. Dermatol Ther (Heidelb). 2016; 6(2): 237-47.

PubMed Abstract | Publisher Full Text | Free Full Text | F1000 Recommendation

13. F Halioua $B$, Cribier $B$, Frey $M$, et al.: Feelings of stigmatization in patients with rosacea. J Eur Acad Dermatol Venereol. 2017; 31(1): 163-8. PubMed Abstract | Publisher Full Text | F1000 Recommendation

14. F Haber R, El Gemayel M: Comorbidities in rosacea: A systematic review and update. J Am Acad Dermatol. 2018; 78(4): 786-792.e8. PubMed Abstract | Publisher Full Text | F1000 Recommendation

15. F Egeberg A, Hansen PR, Gislason GH, et al:: Patients with rosacea have increased risk of dementia. Ann Neurol. 2016; 79(6): 921-8. PubMed Abstract | Publisher Full Text | F1000 Recommendation

16. Holmes AD, Spoendlin J, Chien AL, et al.: Evidence-based update on rosacea 
comorbidities and their common physiologic pathways. J Am Acad Dermatol. 2018; 78(1): 156-66.

PubMed Abstract | Publisher Full Text

17. Tan J, Almeida LM, Bewley A, et al:: Updating the diagnosis, classification and assessment of rosacea: recommendations from the global ROSacea COnsensus (ROSCO) panel. Br J Dermatol. 2017; 176(2): 431-8. PubMed Abstract | Publisher Full Text

18. Schwab VD, Sulk M, Seeliger S, et al:: Neurovascular and neuroimmune aspects in the pathophysiology of rosacea. J Investig Dermatol Symp Proc. 2011; 15(1): $53-62$.

PubMed Abstract | Publisher Full Text | Free Full Text

19. Buhl T, Sulk M, Nowak P, et al:: Molecular and Morphological Characterization of Inflammatory Infiltrate in Rosacea Reveals Activation of Th1/Th17 Pathways. J Invest Dermatol. 2015; 135(9): 2198-208

PubMed Abstract | Publisher Full Text

20. Kelhälä HL, Palatsi R, Fyhrquist N, et al.: IL-17/Th17 pathway is activated in acne lesions. PLOS One. 2014; 9(8): e105238.

PubMed Abstract | Publisher Full Text | Free Full Text

21. Kistowska M, Meier B, Proust T, et al.: Propionibacterium acnes promotes Th17 and Th17/Th1 responses in acne patients. J Invest Dermatol. 2015; 135(1): $110-8$.

PubMed Abstract | Publisher Full Text

22. Agak GW, Qin M, Nobe J, et al.: Propionibacterium acnes Induces an IL-17 Response in Acne Vulgaris that Is Regulated by Vitamin A and Vitamin D. J Invest Dermatol. 2014; 134(2): 366-73.

PubMed Abstract | Publisher Full Text | Free Full Text

23. Holmes $A D$ : Potential role of microorganisms in the pathogenesis of rosacea. J Am Acad Dermatol. 2013; 69(6): 1025-32.

PubMed Abstract | Publisher Full Text

24. Murillo N, Aubert J, Raoult D: Microbiota of Demodex mites from rosacea patients and controls. Microb Pathog. 2014; 71-72: 37-40. PubMed Abstract | Publisher Full Text

25. Murillo N, Mediannikov O, Aubert J, et al:: Bartonella quintana detection in Demodex from erythematotelangiectatic rosacea patients. Int J Infect Dis. 2014; 29: $176-7$

PubMed Abstract | Publisher Full Text

26. Koçak M, Yağli S, Vahapoğlu G, et al.: Permethrin $5 \%$ cream versus metronidazole $0.75 \%$ gel for the treatment of papulopustular rosacea. A randomized double-blind placebo-controlled study. Dermatology. 2002; 205(3) 265-70.

PubMed Abstract | Publisher Full Text

27. Rebora A, Drago F, Picciotto A: Helicobacter pylori in patients with rosacea. $A m$ J Gastroenterol. 1994; 89(9): 1603-4. PubMed Abstract

28. Kolibásová K, Tóthová I, Baumgartner J, et al.: Eradication of Helicobacter pylor as the only successful treatment in rosacea. Arch Dermatol. 1996; 132(11): 1393

PubMed Abstract | Publisher Full Text

29. F Jørgensen AR, Egeberg A, Gideonsson R, et al:: Rosacea is associated with Helicobacter pylori: a systematic review and meta-analysis. J Eur Acad Dermatol Venereol. 2017; 31(12): 2010-5.

PubMed Abstract | Publisher Full Text | F1000 Recommendation

30. Yamasaki K, Kanada K, Macleod DT, et al:: TLR2 expression is increased in rosacea and stimulates enhanced serine protease production by keratinocytes. J Invest Dermatol. 2011; 131(3): 688-97. PubMed Abstract | Publisher Full Text | Free Full Text

31. Kim JY, Kim YJ, Lim BJ, et al.: Increased expression of cathelicidin by direc activation of protease-activated receptor 2: possible implications on the pathogenesis of rosacea. Yonsei Med J. 2014; 55(6): 1648-55. PubMed Abstract | Publisher Full Text | Free Full Text

32. Segovia J, Sabbah A, Mgbemena V, et al.: TLR2/MyD88/NF-KB pathway, reactive oxygen species, potassium efflux activates NLRP3/ASC inflammasome during respiratory syncytial virus infection. PLOS One 2012; 7(1): e29695. PubMed Abstract | Publisher Full Text | Free Full Text

33. Meyer-Hoffert U, Schröder JM: Epidermal proteases in the pathogenesis of rosacea. J Investig Dermatol Symp Proc. 2011; 15(1): 16-23. PubMed Abstract | Publisher Full Text

34. Gerber PA, Buhren BA, Steinhoff M, et al:: Rosacea: The cytokine and chemokine network. J Investig Dermatol Symp Proc. 2011; 15(1): 40-7. PubMed Abstract | Publisher Full Text | Free Full Text

35. Steinhoff M, Schauber J, Leyden JJ: New insights into rosacea pathophysiology: a review of recent findings. J Am Acad Dermatol. 2013; 69(6 Suppl 1): S15-26. PubMed Abstract | Publisher Full Tex

36. F Yamasaki K, Di Nardo A, Bardan A, et al:: Increased serine protease activity and cathelicidin promotes skin inflammation in rosacea. Nat Med. 2007; 13(8) $975-80$.

PubMed Abstract | Publisher Full Text | F1000 Recommendation

37. Oikonomopoulou K, Hansen KK, Saifeddine M, et al.: Kallikrein-mediated cell signalling: targeting proteinase-activated receptors (PARs). Biol Chem. 2006; 387(6): 817-24.

PubMed Abstract | Publisher Full Text

38. Steinhoff M, Buddenkotte J, Shpacovitch V, et al.: Proteinase-activated receptors: transducers of proteinase-mediated signaling in inflammation and immune response. Endocr Rev. 2005; 26(1): 1-43.

PubMed Abstract | Publisher Full Text

39. Steinhoff M, Vergnolle N, Young SH, et al:: Agonists of proteinase-activated receptor 2 induce inflammation by a neurogenic mechanism. Nat Med. 2000; 6(2): 151-8.

PubMed Abstract | Publisher Full Text

40. Vergnolle N, Bunnett NW, Sharkey KA, et al:: Proteinase-activated receptor-2 and hyperalgesia: A novel pain pathway. Nat Med. 2001; 7(7): 821-6. PubMed Abstract | Publisher Full Text

41. Shpacovitch VM, Brzoska T, Buddenkotte J, et al:: Agonists of proteinaseactivated receptor 2 induce cytokine release and activation of nuclear transcription factor kappaB in human dermal microvascular endothelial cells. $J$ Invest Dermatol. 2002; 118(2): 380-5.

PubMed Abstract | Publisher Full Text

42. Buddenkotte $\mathrm{J}$, Stroh $\mathrm{C}$, Engels $\mathrm{IH}$, et al: Agonists of proteinase-activated receptor-2 stimulate upregulation of intercellular cell adhesion molecule-1 in primary human keratinocytes via activation of NF-kappa B. J Invest Dermatol. 2005; 124(1): 38-45.

PubMed Abstract | Publisher Full Text

43. Moormann C, Artuc M, Pohl E, et al:: Functional characterization and expression analysis of the proteinase-activated receptor-2 in human cutaneous mast cells. J Invest Dermatol. 2006; 126(4): 746-55. PubMed Abstract | Publisher Full Text

44. F Morizane S, Yamasaki K, Kabigting FD, et al:: Kallikrein expression and cathelicidin processing are independently controlled in keratinocytes by calcium, vitamin $D_{3}$, and retinoic acid. J Invest Dermatol. 2010; 130(5): 1297-306. PubMed Abstract | Publisher Full Text | Free Full Text | F1000 Recommendation

45. Demeriian M, Hachem JP, Tschachler E, et al.: Acute modulations in permeability barrier function regulate epidermal cornification: role of caspase14 and the protease-activated receptor type 2. Am J Pathol. 2008; 172(1): 86-97. PubMed Abstract | Publisher Full Text | Free Full Text

46. Elias PM: Skin barrier function. Curr Allergy Asthma Rep. 2008; 8(4): 299-305. PubMed Abstract | Publisher Full Text | Free Full Text

47. F Drago F, De Col E, Agnoletti AF, et al:: The role of small intestinal bacteria overgrowth in rosacea: A 3-year follow-up. J Am Acad Dermatol. 2016; 75(3): e113-e115

PubMed Abstract | Publisher Full Text | F1000 Recommendation

48. Parodi A, Paolino S, Greco A, et al:: Small intestinal bacterial overgrowth in rosacea: clinical effectiveness of its eradication. Clin Gastroenterol Hepatol. 2008; 6(7): 759-64

PubMed Abstract | Publisher Full Text

49. $F$ Drago $F$, Ciccarese G, Parodi A: Effects of the treatment for small intestine bacterial overgrowth on rosacea. J Dermatol. 2017; 44(12): e321. PubMed Abstract | Publisher Full Text | F1000 Recommendation

50. Weinstock LB, Steinhoff M: Rosacea and small intestinal bacterial overgrowth Prevalence and response to rifaximin. J Am Acad Dermatol. 2013; 68(5): 875-6. PubMed Abstract | Publisher Full Text

51. Jarmuda S, O'Reilly N, Zaba R, et al.: Potential role of Demodex mites and bacteria in the induction of rosacea. J Med Microbiol. 2012; 61(Pt 11): 1504-10. PubMed Abstract | Publisher Full Text

52. Steinhoff M, Buddenkotte J, Aubert J, et al:: Clinical, cellular, and molecular aspects in the pathophysiology of rosacea. $J$ Investig Dermatol Symp Proc. 2011; 15(1): 2-11

PubMed Abstract | Publisher Full Text | Free Full Text

53. F Sulk M, Seeliger S, Aubert J, et al.: Distribution and expression of nonneuronal transient receptor potential (TRPV) ion channels in rosacea. $J$ Invest Dermatol. 2012; 132(4): 1253-62.

PubMed Abstract | Publisher Full Text | Free Full Text | F1000 Recommendation

54. F Everaerts W, Gees M, Alpizar YA, et al.: The capsaicin receptor TRPV1 is a crucial mediator of the noxious effects of mustard oil. Curr Biol. 2011; 21(4): $316-21$

PubMed Abstract | Publisher Full Text | F1000 Recommendation

55. Caterina MJ, Schumacher MA, Tominaga M, et al:: The capsaicin receptor: a heatactivated ion channel in the pain pathway. Nature. 1997; 389(6653): 816-24. PubMed Abstract | Publisher Full Text

56. F Story GM, Peier AM, Reeve AJ, et al:: ANKTM1, a TRP-like channel expressed in nociceptive neurons, is activated by cold temperatures. Cell. 2003; 112(6): 819-29.

PubMed Abstract | Publisher Full Text | F1000 Recommendation

57. $\mathrm{F}$ Moore $\mathrm{C}$, Cevikbas $\mathrm{F}$, Pasolli $\mathrm{HA}$, et al:: UVB radiation generates sunburn pain and affects skin by activating epidermal TRPV4 ion channels and triggering endothelin-1 signaling. Proc Natl Acad Sci U S A. 2013; 110(34): E3225-34.

PubMed Abstract | Publisher Full Text | Free Full Text | F1000 Recommendation

58. Mihara S, Shibamoto $\mathrm{T}$ : The role of flavor and fragrance chemicals in TRPA1 (transient receptor potential cation channel, member A1) activity associated with allergies. Allergy Asthma Clin Immunol. 2015; 11(1): 11.

PubMed Abstract | Publisher Full Text | Free Full Text

59. Drummond PD, Su D: Endothelial and axon reflex vasodilatation to acetylcholine in rosacea-affected skin. Arch Dermatol Res. 2012; 304(2): 133-7. PubMed Abstract | Publisher Full Text 
60. Steinhoff M, Ständer S, Seeliger S, et al:: Modern aspects of cutaneous neurogenic inflammation. Arch Dermatol. 2003; 139(11): 1479-88. PubMed Abstract | Publisher Full Text

61. Aubdool AA, Brain SD: Neurovascular aspects of skin neurogenic inflammation. J Investig Dermatol Symp Proc. 2011; 15(1): 33-9. PubMed Abstract | Publisher Full Text

62. Baylie RL, Brayden JE: TRPV channels and vascular function. Acta Physiol (Oxf). 2011; 203(1): 99-116.

PubMed Abstract | Publisher Full Text | Free Full Text

63. Madva EN, Granstein RD: Nerve-derived transmitters including peptides influence cutaneous immunology. Brain Behav Immun. 2013; 34: 1-10. PubMed Abstract | Publisher Full Text | Free Full Text

64. Hajna Z, Sághy É, Payrits M, et al.: Capsaicin-Sensitive Sensory Nerves Mediate the Cellular and Microvascular Effects of $\mathrm{H}_{2} \mathrm{~S}$ via TRPA1 Receptor Activation and Neuropeptide Release. J Mol Neurosci. 2016; 60(2): 157-70. PubMed Abstract | Publisher Full Text

65. Steinhoff M, Schmelz M, Schauber J: Facial Erythema of Rosacea - Aetiology, Different Pathophysiologies and Treatment Options. Acta Derm Venereol. 2016; 96(5): 579-86.

PubMed Abstract | Publisher Full Text

66. Metzler-Wilson K, Toma K, Sammons DL, et al:: Augmented supraorbital skin sympathetic nerve activity responses to symptom trigger events in rosacea patients. J Neurophysiol. 2015; 114(3): 1530-7.

PubMed Abstract | Publisher Full Text | Free Full Text

67. Del Rosso JQ: Management of facial erythema of rosacea: what is the role of topical $\alpha$-adrenergic receptor agonist therapy? J Am Acad Dermatol. 2013; 69(6 Suppl 1): S44-56.

PubMed Abstract | Publisher Full Text

68. Chang ALS, Raber I, Xu J, et al.: Assessment of the genetic basis of rosacea by genome-wide association study. J Invest Dermatol. 2015; 135(6): 1548-55. PubMed Abstract | Publisher Full Text | Free Full Tex

69. F Woo YR, Lim JH, Cho DH, et al.: Rosacea: Molecular Mechanisms and Management of a Chronic Cutaneous Inflammatory Condition. Int J Mol Sci. 2016; 17(9): pii: E1562.

PubMed Abstract | Publisher Full Text | Free Full Text | F1000 Recommendation

70. van Steensel MA, Badeloe S, Winnepenninckx V, et al.: Granulomatous rosacea and Crohn's disease in a patient homozygous for the Crohn-associated NOD2/ CARD15 polymorphism R702W. Exp Dermatol. 2008; 17(12): 1057-8.

PubMed Abstract | Publisher Full Text

71. $\mathrm{F}$ Egeberg $\mathrm{A}$, Hansen PR, Gislason $\mathrm{GH}$, et al:: Clustering of autoimmune diseases in patients with rosacea. J Am Acad Dermatol. 2016; 74(4): 667-72.e1. PubMed Abstract | Publisher Full Text | F1000 Recommendation

72. Schaller M, Schöfer H, Homey B, et al:: Rosacea Management: Update on general measures and topical treatment options. J Dtsch Dermatol Ges. 2016; 14 Suppl 6: 17-27.

PubMed Abstract | Publisher Full Text

73. Schaller M, Almeida LM, Bewley A, et al.: Rosacea treatment update: recommendations from the global ROSacea COnsensus (ROSCO) panel. $\mathrm{Br} \mathrm{J}$ Dermatol. 2017; 176(2): 465-71.

PubMed Abstract | Publisher Full Text

74. Reinholz M, Ruzicka T, Steinhoff M, et al.: Pathogenesis and clinical presentation of rosacea as a key for a symptom-oriented therapy. J Dtsch Dermatol Ges. 2016; 14 Suppl 6: 4-15.

PubMed Abstract | Publisher Full Tex

75. Jackson JM, Fowler J, Moore A, et al.: Improvement in facial erythema within $\mathbf{3 0}$ minutes of initial application of brimonidine tartrate in patients with rosacea. J Drugs Dermatol. 2014; 13(6): 699-704. PubMed Abstract

76. Fowler J Jr, Jackson M, Moore A, et al:: Efficacy and safety of once-daily topical brimonidine tartrate gel $0.5 \%$ for the treatment of moderate to severe facial erythema of rosacea: results of two randomized, double-blind, and vehiclecontrolled pivotal studies. J Drugs Dermatol. 2013; 12(6): 650-6. PubMed Abstract

77. Docherty JR, Steinhoff M, Lorton D, et al: Multidisciplinary Consideration of Potential Pathophysiologic Mechanisms of Paradoxical Erythema with Topical Brimonidine Therapy. Adv Ther. 2016; 33(11): 1885-95. PubMed Abstract | Publisher Full Text | Free Full Text

78. F Draelos ZD, Gold MH, Weiss RA, et al:: Efficacy and safety of oxymetazoline cream $1.0 \%$ for treatment of persistent facial erythema associated with rosacea: Findings from the 52-week open label REVEAL trial. J Am Acad Dermatol. 2018; 78(6): 1156-63.

PubMed Abstract | Publisher Full Text | F1000 Recommendation

79. F Holmes AD, Steinhoff M: Integrative concepts of rosacea pathophysiology clinical presentation and new therapeutics. Exp Dermatol. 2017; 26(8): 659-67. PubMed Abstract | Publisher Full Text | F1000 Recommendation

80. F Pietschke $\mathrm{K}$, Schaller M: Long-term management of distinct facial flushing and persistent erythema of rosacea by treatment with carvedilol. J Dermatolog Treat. 2018; 29(3): 310-3.

PubMed Abstract | Publisher Full Text | F1000 Recommendation

81. F Hofmann MA, Lehmann P: Physical modalities for the treatment of rosacea. J Dtsch Dermatol Ges. 2016; 14 Suppl 6: 38-43. PubMed Abstract | Publisher Full Text | F1000 Recommendation

82. F Scharschmidt TC, Yost JM, Truong SV, et al:: Neurogenic rosacea: a distinct clinical subtype requiring a modified approach to treatment. Arch Dermatol. 2011; 147(1): 123-6.

PubMed Abstract | Publisher Full Text | Free Full Text | F1000 Recommendation

83. F Stein L, Kircik L, Fowler J, et al.: Efficacy and safety of ivermectin $1 \%$ cream in treatment of papulopustular rosacea: results of two randomized, doubleblind, vehicle-controlled pivotal studies. J Drugs Dermatol. 2014; 13(3): 316-23. PubMed Abstract | F1000 Recommendation

84. Breneman DL, Stewart D, Hevia O, et al:: A double-blind, multicenter clinical tria comparing efficacy of once-daily metronidazole 1 percent cream to vehicle in patients with rosacea. Cutis. 1998; 61(1): 44-7.

PubMed Abstract

85. Dahl MV, Katz HI, Krueger GG, et al:: Topical metronidazole maintains remissions of rosacea. Arch Dermatol. 1998; 134(6): 679-83. PubMed Abstract | Publisher Full Text

86. Jorizzo JL, Lebwohl M, Tobey RE: The efficacy of metronidazole $1 \%$ cream once daily compared with metronidazole $1 \%$ cream twice daily and their vehicles in rosacea: A double-blind clinical trial. J Am Acad Dermatol. 1998; 39(3): $502-4$.

PubMed Abstract | Publisher Full Tex

87. F Thiboutot D, Thieroff-Ekerdt R, Graupe K: Efficacy and safety of azelaic acid (15\%) gel as a new treatment for papulopustular rosacea: Results from two vehicle-controlled, randomized phase III studies. J Am Acad Dermatol. 2003, 48(6): 836-45.

PubMed Abstract | Publisher Full Text | F1000 Recommendation

88. Del Rosso JQ: Medical treatment of rosacea with emphasis on topical therapies. Expert Opin Pharmacother. 2004; 5(1): 5-13. PubMed Abstract | Publisher Full Text

89. Schaller M, Schöfer H, Homey B, et al:: State of the art: Systemic rosacea management. J Dtsch Dermatol Ges. 2016; 14 Suppl 6: 29-37. PubMed Abstract | Publisher Full Tex

90. F Fink C, Lackey J, Grande DJ: Rhinophyma: A Treatment Review. Dermatol Surg. 2018; 44(2): 275-82.

PubMed Abstract | Publisher Full Text | F1000 Recommendation

91. Uslu M, Savk E, Karaman G, et al:: Rosacea treatment with intermediate-dose isotretinoin: Follow-up with erythema and sebum measurements. Acta Derm Venereol. 2012; 92(1): 73-7.

PubMed Abstract | Publisher Full Text

92. van Zuuren EJ, Fedorowicz Z: Interventions for Rosacea. JAMA. 2015; 314(22): 2403-4.

PubMed Abstract | Publisher Full Text

93. Ranu H, Lee J, Hee TH: Therapeutic hotline: Successful treatment of Morbihan's disease with oral prednisolone and doxycycline. Dermatol Ther. 2010; 23(6): 682-5.

PubMed Abstract | Publisher Full Text

94. F Schaller M, Pietschke K: Successful therapy of ocular rosacea with topical ivermectin. Br J Dermatol. 2018; 179(2): 520-1.

PubMed Abstract | Publisher Full Text | F1000 Recommendation

95. Steinhoff M, Vocanson M, Voegel JJ, et al.: Topical Ivermectin $10 \mathrm{mg} / \mathrm{g}$ and Oral Doxycycline $40 \mathrm{mg}$ Modified-Release: Current Evidence on the Complementary Use of Anti-Inflammatory Rosacea Treatments. Adv Ther. 2016; 33(9): 1481-501.

PubMed Abstract | Publisher Full Text | Free Full Text 


\section{Open Peer Review}

\section{Current Peer Review Status:}

\section{Editorial Note on the Review Process}

Faculty Reviews are review articles written by the prestigious Members of Faculty Opinions. The articles are commissioned and peer reviewed before publication to ensure that the final, published version is comprehensive and accessible. The reviewers who approved the final version are listed with their names and affiliations.

\section{The reviewers who approved this article are:}

\section{Version 1}

\section{Jacob Pontoppidan Thyssen}

Department of Dermatology and Allergy, Herlev and Gentofte Hospital, University of Copenhagen, Hellerup, DK-2900, Denmark

Competing Interests: No competing interests were disclosed.

\section{Adam Reich iD}

Department of Dermatology, University of Rzeszów, Rzeszów, Poland

Competing Interests: No competing interests were disclosed.

\section{Steven R Feldman}

Department of Dermatology, Wake Forest School of Medicine, Winston-Salem, NC, USA

Competing Interests: This reviewer has received support from Galderma.

The benefits of publishing with F1000Research:

- Your article is published within days, with no editorial bias

- You can publish traditional articles, null/negative results, case reports, data notes and more

- The peer review process is transparent and collaborative

- Your article is indexed in PubMed after passing peer review

- Dedicated customer support at every stage

For pre-submission enquiries, contact research@f1000.com 